\title{
History of Entertainment Magazines within the Politics of Power and Sexuality
}

\section{Sejarah Majalah Hiburan dalam Politik Kekuasaan dan Seksualitas}

\author{
Formas Juitan Lase \\ Program Studi Ilmu Komunikasi, Universitas Kristen Indonesia \\ formas.juitan@uki.ac.id
}

\begin{abstract}
This article discussed the history of the entertainment magazines in Indonesia. By using the historiography method, this paper interpreted the dynamics of entertainment magazines from its birth until gradually being run over by market competition that coupled with women magazines, television, and pornography. This article also highlighted Sukarno's Political Manifesto in the practice of entertainment magazines during the Guided Democracy era. Entertainment Magazine became an instrument for the dissemination of political jargon through Kebaya. It constructed as a national identity to obstruct western ideology and culture while female sexuality that displayed feminine and sexy in kebaya were objectified through the male gaze.

Keywords: Entertainment Magazines; Sexuality; Sukarno; Political Manifesto

Abstrak

Artikel ini membahas tentang sejarah majalah hiburan yang pernah berkembang pada rejim kekuasaan Sukarno dan Suharto. Dengan menggunakan metode historiografi, tulisan ini mencoba mengintepretasi dan menarasikan dinamika perkembangan majalah hiburan dari lahir, berkembang hingga berangsung-angsur tergilas persaingan pasar dengan majalah wanita, media elektronik dan pornografi. Artikel ini juga menyoroti adanya politik kekuasaan Sukarno dalam praktik majalah hiburan melalui instruksi Manipol USDEK pada masa Demokrasi Terpimpin. Majalah Hiburan menjadi instrumen penyebaran jargon-jargon politik Sukarno salah satunya melalui penggunaan kebaya. Kebaya dikonstruksi sebagai identitas nasional guna menghalau ideologi dan budaya barat. Sementara di sisi lain, seksualitas perempuan yang ditampilkan feminin dan seksi dalam kebaya diobyektifikasi dalam tatapan laki-laki.
\end{abstract}

Kata kunci: Majalah Hiburan; Manipol-USDEK; Seksualitas; Sukarno 


\section{Introduction}

Entertainment magazine is a genre in Indonesian printed media that rarely received a proper amount of portion in the research, especially regarding the history of the press. Furthermore, the researchers mostly only researched the mainstream media and woman magazine. For example, Surjomihardjo (1980), Smith (1983), and Hill (2011), in their attempt to describe the dynamics of mainstream newspapers, seldom mentioned entertainment magazine. Even though in the last chapter of his book, Pers di Masa Order Baru, Hill slightly identified marginal media, such as university media, Islamic media, regional media, and English media (Hill, 2011:135), entertainment magazine was not mentioned at all.

A lack of heed can also be seen from Hill's description of commercial media published in the Sukarno regime. Although the finding is worth noting as the spirit of the newspapers in that era repleted with discourse regarding nationalism, the independence movement, and national character building (Hill, 2011:21), no further explanation about the names of the newspaper and magazine that were categorized as commercial was found, including the type of the contents of the media. It is reasonably problematic considering entertainment magazines were also involved in Sukarno's propaganda agenda (Junaedhie, 1995:42).

Fortunately, Junaedhie, in his book entitled Rahasia Dapur Majalah di Indonesia (1995), and Lesmana, in his book called Porno Dalam Media Massa (1994), attentively documented entertainment magazine that used to be published. These books are vital because only few researchers track the development of marginal media such as entertainment magazines in the history of the Indonesian press. As to Junaedhie, although his book is not solely dedicated for studying entertainment magazines together with other genres described during Sukarno and Suharto era, the study contributes to providing data concerning the development of entertainment magazines. On the other hand, as to Lesmana's work, it provided data regarding newspaper and entertainment magazines which were sent to the court because of the contents violating the social norm, whether in the Sukarno or Suharto era.

With the consideration of entertainment magazine above in mind, this research describes the history and development of entertainment magazines in the Sukarno era and in the opening of Suharto era. The history mentioned here was an interpretation from various sources, mainly from the entertainment magazines themselves and other relevant sources. The researcher relied on books and documents on entertainment magazines that could be tracked in the old book markets, libraries in Jakarta, Semarang, and Yogyakarta, and the old books' website. The main argument of this research is history cannot be separated from the politics of power of the regime wielding power. Entertainment magazines, apart from perpetuating the status quo, also figured in being a political instrument of the regime and developing discourse on women's sexuality in that era.

\section{Methodology}

The approach of the research is qualitative-descriptive and author use the historiography method. Historiography is a research method emphasizing historical description and interpretation. It also involves broader considerations of the power of the culture, social, economy, and politics. It is applied due to those elements are considered influential in shaping history in a specific period (Given, 2008:399; Scannell, 2002: 191).

The application of the historiography in the research was run as follows. Firstly, the researcher executed a step called heuristic or investigation of the sources. In this stage, 
sources were split into two types: primary and secondary. The primary sources were entertainment magazines while the secondary sources were studies, documents, books, and newspapers related to entertainment magazines. In historiography, sources and materials used for reference and analyses are crucial to determining the quality of the result.

Secondly, the author performed a stage called "critique". In this phase, the author separated, verified, and sifted the sources. The sources collected were tabulated according to the needs of the research explanation. After that, the interpretation stage was carried out in which the historical references were analyzed to explain the social and cultural situation developing around 1950-1965, whether in terms of entertainment, politics of power, or discourse on women's sexuality. Lastly, the researcher wrote down the finding. In this step, the researcher narrated all the collected findings.

\section{Results and Discussion}

\section{The Birth of Entertainment Magazine: an Interpretation}

Terang Boelan magazine that first published in 1939 deemed as the first entertainment magazine at that time. This consideration referred to several notes: the first is the tagline of the Terang Boelan, namely "the first entertainment magazine in Indonesia." The researcher utterly realized that the claim should be scrutinized further to prove whether there is no other similar magazine born before Terang Boelan. The researcher tried to confirm this through literature review, whether through relevant documentation search or national and regional libraries. The researcher found that no magazine older than Terang Boelan, notably magazine published in the Indonesian language. This magazine accommodated political, historical, and international news, but it also contained pictures of sexy women and short stories with sexual themes (Lase, 2015:115).

Junaedhie (1995:34) wrote that “...for the first time, Indonesia was avalanched by magazines which explored sexual elements that were reflected through the skin pictures and the natures and material of the writing." These magazines stated themselves as adult magazines that produced sexual content with taglines such as "entertainment for adults," "entertainment for man and woman," or "for over 17 years old." Some entertainment magazines that signified themselves as adult entertainment, apart from Terang Boelan, were Mesra, Roman, Nafsu, Roman Asmara, and Adam \& Eva. Most of the contents of these magazines were fictional short stories and serials. In the stories published, sketches of sexy women inserted even though the pictures were not related to the stories. On the other hand, another rubric contained jokes, such as in Mesra No 6 April 1956 which incorporated funny stories regarding husband and wife under the rubric "Gelak Sedjenak (Laugh For A While)."

In addition to the magazines above, Varia and Selecta were also categorized as adult magazines. Junaedhie (1995:37-38) described that "in each publication, Varia presented writings and selected sex appealing pictures, mostly about beautiful ladies. [...] this magazine accommodated 1001 writing on various topics. There were serialized short stories, such as "Bernapas Dalam Lumpur" (Breathing Under The Mud) written by Zaenal Abdi, which was subsequently filmed by Turino Djunaedi..." Selecta, on the other hand, “...was widely known as audacious because serving writing and pictures that can be categorized pornography. One of the articles in 1972 entitled "Isyarat Sex" obtained an official rebuke from the Ministry of Information." The other entertainment magazines that are successfully tracked by the researcher are listed in table 1 below: 
Tabel 1. Entertainment Magazine Published between 1939 and 1980

\begin{tabular}{|c|c|c|c|c|}
\hline Title & $\begin{array}{c}\text { Year of } \\
\text { Publication }\end{array}$ & Publisher & Editor & City \\
\hline $\begin{array}{l}\text { Terang } \\
\text { Bulan }\end{array}$ & 1939 & $\begin{array}{l}\text { Badan Penerbit } \\
\text { Terang Bulan }\end{array}$ & Imam Supardi & Surabaya \\
\hline Moestika & 1948 & - & $\begin{array}{l}\text { Gan Kansing, } \\
\text { Gan Sanhok dan } \\
\text { Lie Gioksien }\end{array}$ & Surabaya \\
\hline $\begin{array}{l}\text { Roman } \\
\text { Kenjtana }\end{array}$ & 1952 & $\begin{array}{l}\text { Noeniek Press } \\
\text { Service. }\end{array}$ & $\begin{array}{l}\text { MS. Joenoes } \\
\text { Loebis }\end{array}$ & Jakarta \\
\hline Tjermin & $1954 ?$ & - & - & Surabaya \\
\hline Roman & 1954 & $\begin{array}{l}\text { Sudjati S.A. } \\
\text { (Interpress) }\end{array}$ & Sudjati SA & Jakarta \\
\hline Monalisa & 1950 & - & $\begin{array}{l}\text { Syamsuddin } \\
\text { Lubis }\end{array}$ & Medan \\
\hline Mesra & 1950 & $\begin{array}{l}\text { Pers - Usaha ex } \\
\text { peladjar - } \\
\text { Pedjoang Genie II } \\
\text { Surakarta }\end{array}$ & - & Jakarta \\
\hline Amor & $1950 ?$ & Penerbit Nasional & - & Bandung \\
\hline Djuwita & $1950 ?$ & Penerbit Nasional & - & Bandung \\
\hline Holidays & $1950 ?$ & Penerbit Nasional & - & Bandung \\
\hline Gembira & $1950 ?$ & Penerbit Nasional & - & Bandung \\
\hline $\begin{array}{l}\text { Pusparaga } \\
m\end{array}$ & $1950 ?$ & Penerbit Nasional & - & Bandung \\
\hline Sensasi & $1950 ?$ & Penerbit Nasional & - & Bandung \\
\hline Tjempaka & $1950 ?$ & Penerbit Nasional & - & Bandung \\
\hline Venus & $1950 ?$ & Penerbit Nasional & - & Cirebon \\
\hline Nafsu & 1956 & $\begin{array}{l}\text { Noeniek Press } \\
\text { Service. }\end{array}$ & $\begin{array}{l}\text { MS. Joenoes } \\
\text { Loebis }\end{array}$ & Jakarta \\
\hline Genit & - & $\begin{array}{l}\text { U.P. Puspa } \\
\text { Kentjana }\end{array}$ & Si Uma. & Jakarta \\
\hline $\begin{array}{l}\text { Tjinta } \\
\text { Mesra }\end{array}$ & 1956 & PP Analisa & Sjamsudin & Jakarta \\
\hline $\begin{array}{l}\text { Roman } \\
\text { Asmara }\end{array}$ & 1956 & - & $\begin{array}{l}\text { A Aslyan } \\
\text { Djohansjach }\end{array}$ & Surabaya \\
\hline Tjitra & 1956 & $\begin{array}{l}\text { Penerbit Widya } \\
\text { Pustaka Bandung }\end{array}$ & - & Bandung \\
\hline Bikini & 1956 & - & Toni Suprapto & Yogyakarta \\
\hline New Look & 1956 & N. V. Tjermin & $\begin{array}{l}\text { T. Nour H. } \\
\text { Kande Sudharto }\end{array}$ & Surabaya \\
\hline Merdeka & 1957 & $\begin{array}{l}\text { N.V. Merdeka } \\
\text { Press }\end{array}$ & $\begin{array}{l}\text { Edi Wawasto, } \\
\text { B.A. }\end{array}$ & Jakarta \\
\hline Varia & 1958 & $\begin{array}{l}\text { Perseroan } \\
\text { Komanditer } \\
\text { "Varia" }\end{array}$ & $\begin{array}{l}\text { Mr. H. Hasibuan/ } \\
\text { Andjar Asmara }\end{array}$ & Jakarta \\
\hline
\end{tabular}




\begin{tabular}{|c|c|c|c|c|}
\hline $\begin{array}{l}\text { Roman } \\
\text { Detektif }\end{array}$ & 1958 & - & $\begin{array}{l}\text { Syamsuddin } \\
\text { Lubis }\end{array}$ & Medan \\
\hline $\begin{array}{l}\text { Drama dan } \\
\text { Sensasi }\end{array}$ & 1958 & - & $\begin{array}{l}\text { Syamsuddin } \\
\text { Lubis }\end{array}$ & Medan \\
\hline $\begin{array}{l}\text { Hiburan } \\
\text { Berantai }\end{array}$ & 1958 & - & $\begin{array}{l}\text { Syamsuddin } \\
\text { Lubis }\end{array}$ & Medan \\
\hline Rindu & - & - & - & Medan \\
\hline Artis & - & - & - & Medan \\
\hline Selecta & 1959 & - & $\begin{array}{l}\text { Syamsuddin } \\
\text { Lubis }\end{array}$ & - \\
\hline Liberty & 1961 & $\begin{array}{l}\text { CV Liberty } \\
\text { Publising Coy }\end{array}$ & Goh Tjing Hok & Suarabaya \\
\hline Ratna & 1961 & $\begin{array}{l}\text { Firma "Usaha } \\
\text { Modern" }\end{array}$ & $\begin{array}{l}\text { Moch. Fadil/Si } \\
\text { Uma }\end{array}$ & Surabaya \\
\hline Mayapada & 1967 & $\begin{array}{l}\text { Jajasan } \\
\text { Perpustakaan } \\
\text { Nasional } \\
\text { (Japernas) }\end{array}$ & Nazirin Zakaria. & Jakarta \\
\hline Vista & 1969 & PT Vistayama & $\begin{array}{l}\text { Achmad Taufik, } \\
\text { Mahmud Fatha }\end{array}$ & Jakarta \\
\hline Viva & 1969 & PT Sintarama & John S. Pangka & Jakarta \\
\hline Varia Nada & 1969 & $\begin{array}{l}\text { Varia Nada } \\
\text { Jakarta }\end{array}$ & Z. Arifin. & Jakarta \\
\hline Variasari & - & - & - & Jakarta \\
\hline Popular & 1969 & CV Populer & $\begin{array}{l}\text { Taufik Abbas/ } \\
\text { Bob. Avianto. } \\
\text { Dharsono. }\end{array}$ & Bandung \\
\hline Moderna & 1969 & $\begin{array}{l}\text { Jajasan Yudha } \\
\text { Press }\end{array}$ & $\begin{array}{l}\text { Sapto/ Umar Nur } \\
\text { Zain }\end{array}$ & Jakarta \\
\hline Mini & 1970 & CV Dharma & $\begin{array}{l}\text { Saptawa } \\
\text { Djajasudharma }\end{array}$ & $\begin{array}{l}\text { Sala/Temangg } \\
\text { ung }\end{array}$ \\
\hline Varia Baru & 1970 & $\begin{array}{l}\text { Jajasan Kasih } \\
\text { Sajang }\end{array}$ & Kadir Purba & Jakarta \\
\hline Violeta & 1971 & $\begin{array}{l}\text { PT Tiara } \\
\text { Indonesia. }\end{array}$ & $\begin{array}{l}\text { S. Wardojo, SM. } \\
\text { Ardan }\end{array}$ & Jakarta \\
\hline $\begin{array}{l}\text { Sport } \\
\text { Fashion } \\
\text { Film }\end{array}$ & 1971 & $\begin{array}{l}\text { PT Ekselerator } \\
\text { Inc. }\end{array}$ & $\begin{array}{l}\text { Aloysius S./ } \\
\text { Marzuki Arifin }\end{array}$ & Jakarta \\
\hline Senyum & 1972 & $\begin{array}{l}\text { PT Gaya Favorit } \\
\text { Press }\end{array}$ & - & Jakarta \\
\hline Senang & 1972 & $\begin{array}{l}\text { PT Samindra } \\
\text { Utama }\end{array}$ & $\begin{array}{l}\text { Sjamsudin/ } \\
\text { Ridwan Idris }\end{array}$ & Jakarta \\
\hline Usia & 1972 & Yayasan Trijaya & Hidajat Rahardjo & Jakarta \\
\hline Spot & 1972 & - & - & - \\
\hline Paradiso & 1973 & $\begin{array}{l}\text { Yayasan Penerbit } \\
\text { Paradies }\end{array}$ & $\begin{array}{l}\text { Andies S. } \\
\text { Sanoesi B.A }\end{array}$ & Jakakrta \\
\hline
\end{tabular}




\begin{tabular}{|c|c|c|c|c|}
\hline Ultra & 1973 & $\begin{array}{l}\text { PT Tiara } \\
\text { Indonesia }\end{array}$ & $\begin{array}{l}\text { S. Wardojo; } \\
\text { Benyamin TR. }\end{array}$ & Jakarta \\
\hline $\begin{array}{l}\text { Peragaan } \\
\text { Olahraga } \\
\text { Perfilman } \\
(P O P)\end{array}$ & 1973 & $\begin{array}{l}\text { PT Ekselerator, } \\
\text { Inc. }\end{array}$ & $\begin{array}{l}\text { Al Sugiyanto/Rey } \\
\text { Hanityo }\end{array}$ & Jakarta \\
\hline Sonata & 1973 & - & - & Jakarta \\
\hline Contessa & 1971 & $\begin{array}{l}\text { Yayasan Tetap } \\
\text { Teguh }\end{array}$ & P.I. Lukmana & Jakarta \\
\hline Tropicana & 1974 & $\begin{array}{l}\text { Yayasan Trikarya } \\
\text { Press }\end{array}$ & $\begin{array}{l}\text { Soejachman/ Z. } \\
\text { Arifin P }\end{array}$ & Jakarta \\
\hline $\begin{array}{l}\text { Adam \& } \\
\text { Eva }\end{array}$ & 1975 & PT Orang Lama & Sjamsudin Lubis & Jakarta \\
\hline Visi & 1979 & - & $\begin{array}{l}\text { Dolly Indra } \\
\text { Nasution, Budi } \\
\text { Saroso, dan Gauri } \\
\text { Nasution }\end{array}$ & Jakarta \\
\hline
\end{tabular}

Source: Marshaled from Various Sources

\section{Entertainment Magazines within the Politics of Power and Sexuality}

Daniel Dhakidae (1991:10-11) contended that the first journalism that practiced by Indonesian pers was mostly have a bold political sense. Political journalism that is referred here is journalism that has a political character, such as journalism that was used by Tirtoadisuryo in Medan Priyayi in 1903 (Dhakidae, 1991:11). Tirtoadisuryo covered the event and political situation there with a 'nationalist perspective' (Hill, 2011:21). Political journalism at that time was encouraged with the presence of political movements that defied Netherland colonialization and raised nationalism tension, such as Budi Oetomo in 1908 and Kongres Pemuda (Youth Congress) in 1928. These journalism practices developed from revolutionary time until the Sukarno period.

However, at the beginning of the independence, a shift from "political journalism to politics of journalism" started to occur, or using Hill words, to "press of struggle, or press that serves political struggle, or media that is proud of being partisan (Hill, 2011:21 23). Hill found that, from 1945 to the 1960s, many newspapers affiliated with political parties. Furthermore, their affiliation then formalized through the Ministry of Information Regulation No.29/SK/M/65 concerning "Basic Norms for the Press Agency for Improving Indonesian Press." The newspapers that affiliated with political parties were Harian Rakyat (published in 1951 and affiliated with the Indonesian Communist Party), Pedoman (1948 - Indonesian Socialist Party), Abadi (1951 - Masyumi Party), and Suluh Indonesia (1953 - Indonesian National Party). The press at that time undisguisedly was used for the political interest of the rulers and political parties to frame and affect public opinion (Hill, 2011:26-28; Smith, 1983:112-114).

In the golden time of "the press of struggle," entertainment magazines were also dragged in the dynamics happening in the Sukarno time. In 1960, when Indonesia entered the era of Demokrasi Terpimpin (guided democracy) after the Presidential Decree on July 5, 1959, Sukarno was keen on creating political jargon and acronyms to barrier the influence of western imperialism (Sukarno, 1965: 556). The essential acronym that related to this topic was a political ideology that initiated by Sukarno called USDEK, a 
political manifesto (abbreviated in Indonesia into Manipol-USDEK). Manipol-USDEK was an acronym and also Sukarno's political philosophy. USDEK is an abstract of a political manifestation upheld by Sukarno consisting of five central points: (1) Indonesian Constitution 1945; (2) Socialism of Indonesia; (3) guided democracy; (4) led economy; (5) Indonesian character.

Sukarno obliged journalists to spread and popularize Manipol-USDEK in any press products available at that time (Smith, 1983:225; Junaedhie, 1995:42). The spread was regulated in the Peperti (Supreme Commander in the State of War and Seight) No 10/October 1960, and it said: "newspaper and magazine oblige to be the spreaders of the political manifesto that become this country direction, for eradicating: imperialism and colonialism, liberalism, and federalism/separatism." Similarly, Smith wrote (1983:226), "in October 1960, the government forbade any form of criticism except for constructive criticism regarding Sukarno politics, and ordered all newspaper publishers, including magazine to be the supporters and defenders, as well as acting as tools to spread political manifesto." Media that did not support Sukarno politics would be threatened, and either they got called by the government or their license got revoked. This consequence was experienced by Abadi (Masyumi) that was banned by Sukarno in 1960 and Pedoman (PSI) that was removed in 1961 (Hill, 2011:27).

Not only printed media, other forms of mass media, such as movies and music were also affected by this instruction of the Soekarno's Manipol-USDEK (Sen \& Hill, 2007:165). The fear about the erosion of local values were triggered by the proliferation of American music, such as Bill Haley and The Comet, which introduced rock and roll in "Rock Around the Clock" movie. Sukarno deemed rock music as a "ngak ngik ngok" (a voice of discordant melody in the Indonesian language) music that is counterrevolutionary. Rather, Sukarno encouraged anyone to popularize Lenso as the counter of western music (Tambayong, 1992:166).

In addition to Sukarno, women organizations also ceaselessly criticized and disdained western imperialism. One of them was Gerakan Wanita Indonesian (Gerwani/ Indonesian Women Movement), which was also a part of the Indonesian Communist Party. Gerwani was not alone since this organization also assisted by other organizations, such as Lekra (Institute for People's Culture), Pemuda Rakyat, Pemuda Islam, and Organisasi Perempuan Islam (Wieringa, 2010:356). Some movies that protested by Gerwani between 1954 to 1965 were The Desert Fox, presented in Rembang, Rock n' Roll, Rock Around the Clock, and Don't Knock the Rocket. Even for the last three, Gerwani asked the related organizations not to be presented in Bandung Film Festival in 1957 (Wieringa, 2010:355-357).

Wieringa explained that Gerwani's criticism toward the moral decadencewhich mostly appeared in the American movies was motivated by the putative effects of the film for women. American films were deemed containing pornography, encouraging raping, and endangering national culture (Wieringa, 2010:255-356). The researcher arguesthat the prevalence of American works is one factor that motivated the emergence of western women pictures in the cover of entertainment magazines. American artists that gained their popularity in Indonesia between 1950 and 1960 were Marilyn Monroe, Lana Turner, Betty Grable, Brigitte Bardot, Raquel Welch, and Gina Lollobrigida. They often appeared in entertainment magazines, such as Varia, Tjitra, Terang Bulan, and Merdeka. These artists were also called sexy symbols because of their presence in the movies and magazines, such as Playboy that published in the United States. 
Based on the observation towards entertainment magazine published around 1960 to 1961, Varia is one of the entertainment magazines that popularized Manipol-USDEK. This entertainment magazine produced national identity and anti-western elements in its covers. It can be seen from the change in the cover page of Varia before and after Manipol-USDEK spreaded in 1960. In the 1959 publications, this entertainment magazine still used western women on the cover page. However, after the instruction of Sukarno's political manifesto, Varia started to feature political themes associated with Sukarno's thought, local identity, culture and customs, traditional dances, and traditional costumes. Through traditional dress, for example, the political slogan manifested through the body of a woman with a traditional kebaya (Indonesian tradition costume) that presented on the cover page.

Figure 1, 2, 3, 4: Varia covers No 47/ March 1959, No 60/ June 1959, No 164/7 June 1961 and No 174/16 August 1961

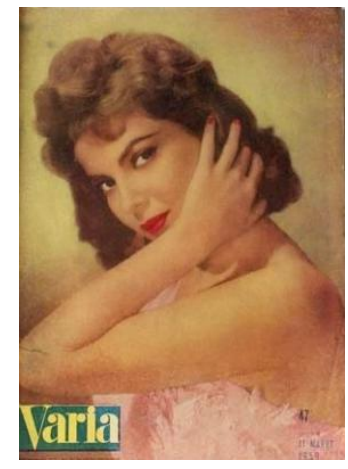

(1)

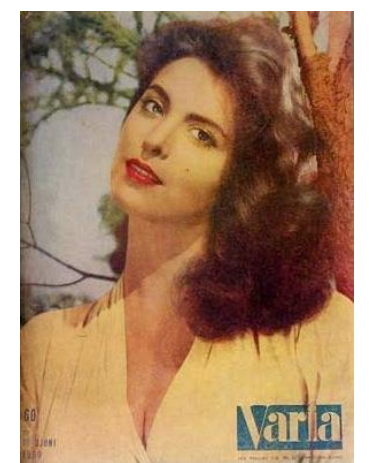

(2)

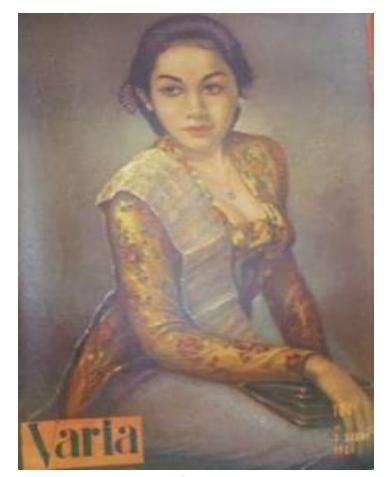

(3)

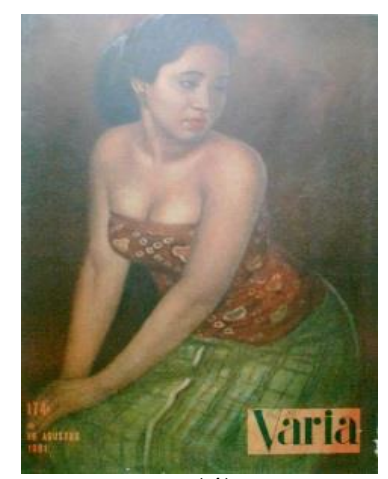

(4)

Sources: Primary Data 2015

Indeed, Varia used to display a picture entitled "a Dress Following USDEK's Principle," in the $12^{\text {th }}$ edition, July 1961 , No 169 , year fourth. In the picture, there was a caption that said: "in the Tenth Women Trade Arena, one of the events was a dress performance that by the designer, R. Suprapti, was called a man dress following USDEK's principle." It illustrated that for securing their companies from political pressure conducted by Sukarno, these magazines tried various methods to survive, including modifying the materials of their magazines so that the license for publishing not be revoked.

Scrutinizing the story above, the manifestation of the instruction of ManipolUSDEK in Varia was targeting women more intensively. On the other hand, men were not strictly defined as women. For example, in the cover page or the picture of "Dress Following USDEK's Principle," women were mostly represented traditionallyby wearing kebaya, while men illustrated as modern. Suryakusuma (2003) said that "kebaya does contain not only cultural meaning but also social, historical, personal, and even ideological and political." To that end, viewing the problem ideologically and politically, kebaya was pointed out by Sukarno as national identity to identify women as a pillar of the nation, while men were juxtaposed with the west through wearing of a suit. This definition can be understood as a dichotomic form that women were supposed to think domestically while men supposed to be visionary and modern. In other words, women were constructed in the private framework while men in the public framework. 
Furthermore, showing women with kebaya can also be interpreted as the construction of women as an object of the male gaze. This is because kebaya understood as a symbol of "feminine" and "sexiness" (Suryakusuma, 2003). Feminine and sexiness image resulted since kebaya shaped the posture of the body and featured the sexual body of the women based on the male gaze.

\section{Figures 5 and 6: Cover and Content of Varia No 169/12 Juli 1961. Source: Primary Data 2015}

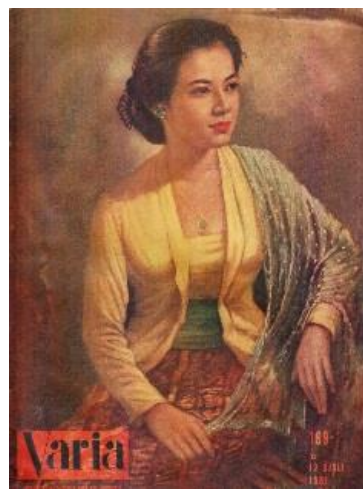

(5)

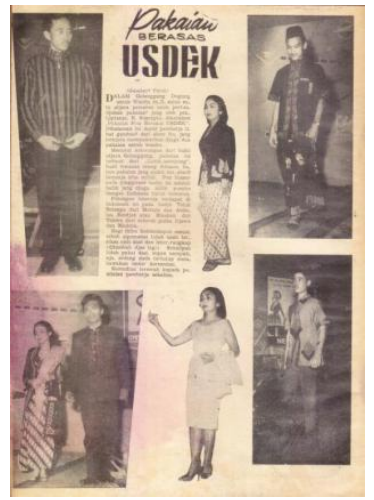

(6)

Source: Primary Data 2015

Based on the explanation above, the instruction of Manipol-USDEK was executed as an attempt to survive in the platform of 'Manipoler' to keep operating according to Sukarno's ideology which dominantly controlled the production process. Sexy women who veiled with traditional kebaya were a strategy of Varia as an entertainment magazine that showed national identity and conventional element instead of western women who portrayed as sexy and appealing.

However, some magazines fought against Sukarno's political manifesto. Although their reasons have not been verified, whether voluntarily or forcefully, one of that magazine, who denied spreading Sukarno's political slogan, was Star Weekly (19521960), an entertainment magazine particularly made for the family. It was founded by PK Ojong, Khoen Woen Sioe, and Injo Beng Goat (Junaedhie, 1995:43), and their focus was international, monetary, and financial news. The editors of the magazine refused to disseminate Sukarno's political manifesto, and even they courageously stood on the different side of the government. Unsurprisingly, the editors of this magazine denied signing a statement of support to spread the political manifesto consisting of 19 points. Consequently, the magazine was banned by Sukarno.

\section{Capitalism and 'Pornography' in The Entertainment Magazine}

The transition of power from Sukarno to Suharto had caused changes in the structure of the press over the period from 1965 to 1998. This condition continues until the reformation era (Susanto, 2013). Political journalism that initially was the spirit of the early journalism, which emphasized idealism and the aspiration of struggle, had transformed and headed to the market and capital concentration, as explained by Makarin in "The Indonesian Press: An Editor Perspective" (1978): 
However, is changing. The "political" type of journalistic venture frequently found in the period of the first and second wave of nationalism in Indonesia is slowly, but surely, making way for the venture in which information will be more and more considered an industrial commodity to be merchandised (Makarim, 1978:273).

Thischanges happened because the new government adopted a liberal economic system. The new government that called the new order regime or crony capitalism had two main characteristics, the government domination, and the centrality of power in the president (Hidayat, 2000:129-131). Capitalization that adopted by the press industry in the new order regime is for accumulating capital through the media specialization. In this new rule, the journalists were actively involved in making business aspect as something inseparable from journalism activity (Hidayat, 2000:143).

In addition to realizing political journalism, which was the spirit of the early journalism of Indonesia and emphasized the aspiration of the struggle and idealism, there was also commercial printed media (Hill, 2011). Entertainment magazine was a printed media that took this step. They tried to strive for profit based on the commodification of the body parts of women and women's sexuality (Junaedhie, 1995:34), especially when Indonesia started to be economically liberal. At that time, the growth of printed media is skyrocketing. Junaedi pointed out that in 1950, the number of weekly, monthly, and periodical magazines hit up to 266 titles, and newspapers with Indonesian languages reached 67 titles. Furthermore, the newspaper with the Dutch language were 11 titles, and newspaper with the Chinese language amounted to 15 titles, mushrooming in the next five years to 351 titles (1995, h. xxiv).

Some arguments noted by Junaedhi showed that, in those years, newspapers and magazines were not run for an ideology that worked for people's interests anymore. Moreover, printed media also experienced a decadence in terms of exercising the code of ethics. The primary purpose of establishing a newspaper was only for financial purposes. "Penerbit brankas" (deposit box publisher), meaning adventurous publishers that strive for profit without idealism, then was attached to those publishers, to signify the phenomenon of commercial media (Junardhie, 1995:34).

The transformation from political journalism to industrial journalism can be tracked through the expansion done by some printed media and the growth of the circulation and advertisement. Dhakidae (1991) pointed out that the revenue of advertisement as an integral part even since the age of political journalism, although it did not contribute significantly to the media management. However, an attempt to look for profit from the publishers cannot be avoided, and advertisement (ads) had been a decisive factor of the life and death of the media industry. Seeing the movement that was made by entertainment magazines in the Sukarno era, it can be said that they also embraced capitalism logics through a process of commercialization of women's sexuality.

Moreover, by seeing advertising rates and the number of advertisements in each edition of entertainment magazines, it can be seen that ads had been a benefactor of the production of entertainment magazines whether in the old order regime or new order regime. Some magazines such as Terang Bulan No 13/October 1954 year eight could accommodate 26 ads in various forms out of 48 pages. That is to say, almost all of the number of pages of the magazine contained advertisements. Roman, which was published in 1950 , reached 40.000 copies for the circulation, and the rate for the ads was Rp2.000, two until three times higher than Terang Boelan, which only hit Rp700. 
The main commodity that was sold by entertainment magazine was non-other than the body of female itself with all the sexual symbols. Since mass media is an industry that produces and distributes commodities (Murdock and Golding, 1977; Mosco, 2009), it is not surprising that the body and sexuality of the women were transformed into a commodity that has value. With that in mind, entertainment magazines in this context would always mediate sexuality to be a commodity that can be consumed by the readers for revenue. Women's sexuality is a strategic way to increase circulation and invite advertisements. From the perspective of political and economic media, advertisement and circulation are inseparable twins. In addition, the increases in the number of distribution of printed media will also increasethe revenue from the advertisement that is earned. This is the reason that the commodification of women's sexuality became a measure that is inevitable for the magazine editors in that era.

\section{The Death of Entertainment Magazine in a Snare of Pornography}

Many factors attributed when these entertainment magazines reached its end; one of them was the rise of press imperium at the beginning of 1970 (Hill, 2011:94). Firstly, Hill contended that this rise impinged on small-scale media. Without joining under the large scale media, such as Gramedia Group, Sinar Kasih Group, Tempo Grafiti, Jawa Pos, Media Indonesia, and Cendana family, which also infiltrate electronic media, it would be demanding for the small press to compete with the big media mainstream (Hill, 2011:97-126). Secondly, it was the rising number of women magazines in the market (Junaedhie, 1995:41; 67). Thirdly, regulations concerning decency violation were applied, whether in the form KUHP (Indonesian Criminal Code), such as in Article 533, Article 282, Paragraph 1 and 2, and PEPERTI No 10/October 1960 (Publication of Newspaper and Magazines in Indonesia) that said: "newspaper and magazines must raise public awareness of Indonesian character, namely by abstain from writing, paintings, clichés, or pictures that are sensational and decrease moral." This last factor will be discussed further in the next part.

One of the entertainment magazine that closed its publication because of the number of regulation that was considered too much with decency and vague in giving a line between sensuality and decency violation was Tjinta Mesra in 1956. The editor wrote: "it dies because the editors have been exhausted with mines that halt the editorial process. The mine is not transparent. That mine is Act of "Decency Violation" that is vague." The magazine could only publish seven editions. Because of the lack of a clear distinction, many editors of small magazines were prosecuted. They were alleged publishing writing or pictures that aroused lust.

In the Sukarno era, the government censors printed media that published sexual contents, nudity, or other forms, which could awake people's desire, were easily criminalized. It was regulated in Peperti No 10/October 1960. Press institution and Common Opinion recorded 15 cases were brought to the court, as well as the owners, over nine years period (1954-1963) (in Lesmana, 1995:10). In 1956, some editors-in-chief of adult entertainment magazines were dragged to the court. One example was Toni Suprapto, the editor-in-chief of Bikini that was fined Rp500 with five days in prison for subsidiary owing to the publication of a short story entitled "Dan Akhirnya Jatuhlah Aminah" (And Finally Aminah Was Fallen).

The editor-in-chief or New Look experienced the same prosecution. He was fined Rp500 and thirty days' subsidiary in prison out of mentioning "kiss" and "big breast" and publishing a picture of men and women kissing. What is more, the district court of Jakarta 
fined Hussyn Umar, another editor in chief of Roman for month imprisonment $\backslash$ because of a short story entitled "Induk Semang" that was deemed obscene (Lesmana, 1995:13$15)$.

Next four years, in 1961, the same case also dragged the person in charge of Djawa Post, Tjio Oen Sik, with a fine Rp3.000 or a month custodial sentence since he published a picture of a nude dancer in Windmill, England. The next two years, the responsible person of Liberty, Goh Tjing Hok, and his vice M.F. Liem Hok Liong, was imprisoned for a month with a six-month trial out of the publication of writing entitled "Masalah Prostitutie" (Prostitute Problems) (Lesmana, 1995:15-16). Apart from the editors of the magazine, at that time, the writer could also be sentenced. One of the victims was Mr. Jussac because of his short writing published in Bikini edition first and second in 1957 entitled "Dan Akhirnya Jatuhlah Aminah," dan "Bulan Madu Temanten Baru" (Honeymoon of New Bride and Groom) (Lesmana, 1995:14).

Pressure towards entertainment magazines was continued following the next regime. Suharto regime was no less robust in eradicating media that published pornography content. Initiation of Act of Anti-Pornography in 1971 and 1984 was also participated in keeping the fire of banning some magazines (Lesmana, 1995:17). In the middle of 1971, the District Court of Jakarta found the editor in chief of Viva, John S Pangka, guilty because he published contents that violated decency in the five different editions in 1970 and four different editions in 1971. Pangka was convicted of violating KUHP Article 282, paragraph 1 concerning decency.

Meanwhile, a worse situation was experienced by Mayapada, Sport Fashion Film, and Senyum in 1971-1972. Not only were they dragged to the court, but their publishing was also banned, and the licenses were revoked (Lesmana, 1995:38; 43; 48). Sports Fashion Film was a sports magazine, clothes and film, but it transformed into an adult entertainment magazine that glorified women's sexuality even until total nudity in 1972 . According to Lesmana, it was caused by the presence of Sondang Napitupulu in the editorial boards. Two editions after his appearance, namely from edition 17th until edition 28th, the magazines received criticisms from the Ministry of Information because of accommodating writing and pictures considered pornography. The 28th edition was the last edition of the magazine spread in the market before the related ministry revoked the license.

Furthermore, there is another vital point from all cases of banning, that women sexuality in the entertainment magazine was always in the discourse of pornography, and in this case, the Ministry of Information and the editors of magazine never reached a clear line consensus on what does it mean by decency violation or pornography. According to the editors of the entertainment magazine, the pictures that they showed did not contain or awake lust, while for the judges, the pictures could arouse desire not only younger people but also all elements in society.

As described by Lesmana, vice editor-in-chief of Senyum, Iman Waluyo, used to say that "editors of Senyum did not have a clear-cut indicator or guidance regarding the border of pornographic writing and pictures as what has been alleged by the Ministry of Information." However, the judges and witnesses argued the inverse. For example, the judges in Viva's case said that "the criteria of porn are pictures and writing that could arouse sexual desire by only seeing or reading. Also, it applies to a thing that violates decency and is considered not palatable." Regarding this topic, another representative opinion came from H.B. Jassin that said: "Pornography is any writings or pictures that are written or drawn intentionally to arouse sexual desire. Pornography creates the 
readers' fantasy to have wings and fly to genital organs that cause sexual desire to rocket (Lesmana, 1995:109).

According to the opinions from the editors of entertainment magazines, there were two points that they wanted to emphasize: (1) they saw sexiness and half-nudity as sensual, and sensual, according to this view, was beautiful and not containing any decency. (2) As long as they did not use a picture of sexual intercourse or other sexual behavior and show vagina or penis openly, those arts cannot be categorized as pornography. However, for the judges and the advocate of anti-pornography, any activity that presented pictures, writing, and even a metaphor of genital organs or sexual activity should be categorized as pornography.

The discussion left an endless problem, even until now. The reason is that each person has different views regarding the signs that may induce sexual desire,trigger sexual phantasy and the clear-cut differences between sensuality and pornography. Consequently, news that bombed the public only about the intriguing effect of pornography. However, a political framing that induced bigotry towards women's genital organs in the public sphere was reawakened with the movements mentioned. As a result, as stated by Gadis Arivia, "a society that its sexual knowledge was constrained breed a society that misunderstands sex. [...], a society that is taught to hate sex breed a hypocrite society (Hartiningsih, 2010)." This narrative was so subtle that not only as if women felt supported and defended, they also felt needing protection, as a feeble individual, with moral rules.

The consequence of these political and moral interests that worked together with country interest is the spread of fear towards women's body. This also made women back in time when they got prisoned, not to mention phobia towards women's bodies and sexuality. The women were affirmed as pillars of morality, the guardians of the holy. However, in reality, the asexual point that was established was not for protecting women but for preserving a specific political group.

In the end, the body and sexuality of women, in this case, was only seen as a commodity that only had two values: economic and moral. The editor of entertainment magazine saw women body as a commodity that is able to be exploited for the profit of the magazines while the others work to protect a particular moral. Concurrently, the women that were the subject and the hive of discussion were abstained and never included.

\section{Conclusion}

The history of entertainment magazines cannot be separated from the political dynamics of the press of struggle, Sukarno's political power, sexuality, and pornography. Within the politics of power and sexuality, entertainment magazines became an instrument for disseminating the jargon of Sukarno's political manifesto. The instruction was manifested trough women's sexuality and body in the veiled of kebaya in entertainment magazines. Women's bodies and sexuality were used to create a national identity that halted western ideology and culture. On the other hand, women's sexuality that shown as feminine and sexy in the kebaya was objectified in the men's gaze. Eventually, entertainment magazines went bankrupt due to competition with women magazine and electronic media, and more importantly, because of the snares of pornography law. Pornography still left a discussion that has not ended. However, the debate was limited to economic, political, and moral issues. As a result, only the intrigues of pornography that was spread in the public space. Furthermore, the emergence of 
framing and political narrative revived the bigotry of women's sexuality in the public sphere, and it was started with entertainment magazines.

\section{References}

Dhakidae, D. (1991). The State, The Rise of Capital and the fall of Political Journalism: Political Economy of Indonesia News Industry. Disertasi PhD tidak diterbitkan, Ithaca, New York: Cornell University.

Given, Lisa M (2008). The Sage Encyclopedia of Qualitative Research Methods. USA: SAGE Publications, Inc.

Golding, Peter \& Graham Murdock. (1997). The Political Economy of The Media Volume I. United Kingdom: Edward Elgar Publishing Limited.

Hartiningsi, Maria. (2010). Kearifan Tubuh Perempuan Hanya Bisa Dicerna dengan Kecerdasan.[http://health.kompas.com/read/2010/07/30/18535387/Kearifan.Tubu h.Perempuan.Hanya.Bisa.Dicerna.dengan.Kecerdasan] (Diakses 30 April 2015).

Hidayat, Dedy Nur, (2000). 'Pers Dalam Kontradiksi Kapitalisme Orde Baru' dalam Dedy Nur Hidayat dkk, Pers dalam “Revolusi Mei”: Runtuhnya sebuah Hegemoni. Jakarta: Gramedia Pustaka Utama.

Hill, David T. (2011). Pers di Massa Orde Baru. Penerjemah: Gita Widya L.S. Jakarta: Yayasan Obor.

Junaedhie, Kurniawan. (1995). Rahasia Dapur Majalah di Indonesia. Jakarta: Gramedia Pustaka Utama.

Lase. Formas Juitan. (2015). Menjual Wanita Hiburan: Pembentukan Citra Seksual dalam Cerpen pada Majalah Hiburan Terbitan 1950-1965. Jurnal Konvergensi, $1(2), 106-123$.

Lesmana, Tjipta. (1995). Pornografi dalam Media Massa. Jakarta: Penebar Swadaya.

Makarim, N.A. (1978). 'The Indonesian Press: an Editor's Perspective' in K.D. Jackson and L.Pye (eds) political Power and Communication in Indonesia, Berkeley, CA: University of California Press.

Mosco, Vincent. (2009). The Political Economy of Communication, $2^{\text {nd }}$ Edition. London: Sage Publication

Scannell, Paddy (2002). History, Media and Communication dalam Klaus Bruhn Jensen (eds) A Handbook of Media and Communication Research: Qualitative and Quantitative Methodologies. London \& New York: Routledge.

Sen, Krishna \& David T. Hil. (2007). Media, Culture, and Politics in Indonesia. Equinox Publishing.

Smith, Edward C. (1983). Sejarah Pemberedelan Pers di Indonesia (Terj. Atmakusumah). Jakarta: Grafiti Pers.

Sukarno. (1965). Di Bawah Bendera Revolusi Jilid II. Jakarta: Panitia Penerbit Di Bawah Bendera Revolusi.

Surjomihardjo, Abdurrachman. (1980). Beberapa Segi Perkembangan Sejarah Pers di Indonesia. Jakarta: Departemen Penerangan RI.

Suryakusuma, Julia. (2003). Membaca Kebaya.

[http://www.victoriacattoni.net/downloads/JuliaSurya_BahasaIndonesia.pdf]

(Diakses 16 Juli 2015).

Susanto, Eko Harry. (2017). Media Massa, Pemerintah dan Pemilik Modal. Jurnal Aspikom 1 (6), 477-484.

Tambayong, Yapi. (1992). Ensiklopedia Musik Jilid II. Jakarta: Cipta Adi. 
Wieringa, Saskia E. (2010). Penghancuran Gerakan Perempuan, Politik Seksual di Indonesia Pascakejatuhan PKI. Penerjemah: Harsutejo. Yogyakarta: Galangpress. 